\title{
Widely Applicable PCR Markers for Sex Identification in Birds
}

\section{Michael N. Romanov ${ }^{a}{ }^{*}$, Adam M. Betuel ${ }^{b}$, Leona G. Chemnick ${ }^{c}$, Oliver A. Ryder ${ }^{c}$,}

Roman O. Kulibaba ${ }^{d}$, Oleksandr V. Tereshchenko ${ }^{e}$, William S. Payne ${ }^{f}$, Phillip C. Delekta $^{f}$, Jerry B. Dodgson $f$, Elaina M. Tuttle ${ }^{b}$ and Rusty A. Gonser ${ }^{b}$

${ }^{a}$ Comparative and Functional Genomics Group, School of Biosciences, University of Kent, Canterbury, Kent, CT2 7NJ, UK

${ }^{b}$ The Center for Genomic Advocacy, Department of Biology, Indiana State University, $200 N 7^{\text {th }}$ Street, Terre Haute, IN 47809, USA

${ }^{c}$ Genetics Division, San Diego Zoo Institute for Conservation Research, 15600 San Pasqual Valley Road, Escondido, CA 92027, USA

${ }^{d}$ Institute of Animal Science, National Academy of Agrarian Sciences of Ukraine, 7th Guards Army Street, 3, Kulinichi, Kharkov District, Kharkiv Region, 62404, Ukraine

e State Poultry Research Station, National Academy of Agrarian Sciences of Ukraine, Birky, Zmiiv District, Kharkiv Region 63421, Ukraine

${ }^{f}$ Department of Microbiology and Molecular Genetics, Biomedical and Physical Sciences Bldg., 567 Wilson Road, Michigan State University, East Lansing, MI 48824, USA

*e-mail:m.romanov@kent.ac.uk 


\begin{abstract}
To aid in avian sex determination if birds are not sexually dimorphic and/or they are sexually immature, several molecular assays involving the polymerase chain reaction (PCR) have been developed. To test in a variety of domestic and wild avian species applicability of five sexing assays: previously described four assays based on nucleotide sequence differences between the $\mathrm{Z}$ and $\mathrm{W}$ copy of the chicken chromodomain-helicase-DNA-binding protein gene ( $C H D 1 Z$ and $C H D 1 \mathrm{~W})$, and a new sexing marker using the ubiquitin associated protein 2 (UBAP2) gene sequence. At least one molecular sexing marker was successful in 84 out of 88 examined species across 13 avian orders. These assays may be useful in breeding management of domestic and wild birds as well as in studies of avian ecology, population genetics, embryology and transgenesis.
\end{abstract}

Keywords: Aves, birds, DNA markers, PCR-based sexing 


\section{INTRODUCTION}

Molecular sex identification methods in domestic and wild birds are essential for species in which no or weak sexual dimorphism is evident either at hatch, maturity or in ovo. The usefulness of DNA-based sex determination has been demonstrated for evolutionary studies, ecological and conservation issues, and management of endangered species in the wild and captivity (e.g. [1-6]). Previously used sexdetermination methods, involving traditional autosexing based on external traits, vent sexing and surgical gonad examination (e.g. [7]) and, later, sex-specific analyses of karyotypes and the amount of DNA per cell (e.g. [8-10]) have been supplemented or replaced with gender-specific DNA fingerprints. Because in birds the homogametic sex is the male, with two $\mathrm{Z}$ chromosomes, and the heterogametic sex is the female, with one $\mathrm{Z}$ and one $\mathrm{W}$ chromosome, these techniques primarily employ repetitive (e.g. [11-14]), non-repetitive [15] or coding regions on the $\mathrm{W}$ chromosome that are absent or different from their homologs on the $\mathrm{Z}$ chromosome.

Polymerase chain reaction (PCR)-based markers provide rapid and inexpensive assays for avian Z/W sex determination. Most of these markers depend on the polymorphism between two conserved gene homologs, $C H D 1 Z$ and $C H D 1 W$ (e.g. [16-18]), both encoding a chromodomain-helicase-DNA-binding protein that plays an important role in gene regulation. The aim of this study was to examine the range of applicability of four existing $C H D 1$-based sex markers [19-22] in poultry and wild avian species, and to expand the repertoire of molecular genetic markers that are applicable for determining gender in young and adult birds, embryos, and cell cultures.

\section{MATERIALS AND METHODS}

\section{Experimental birds and DNA samples}

In all, we examined 88 domestic and wild avian species across 13 orders (Tables 1 to 5) including: Galliformes (nine species), Anseriformes (two species), Cuculiformes (four 
species), Psittaciformes (29 species), Strigiformes (one species), Columbiformes (seven species), Gruiformes (two species), Ciconiiformes (three species), Falconiformes (seven species), Cathartiformes (one species), Charadriiformes (two species), Procellariiformes (one species), and Passeriformes (20 species). Domestic Chicken (Smoky line; [23]) and its ancestor, Red Jungle Fowl (UCD001 line; [24]) (Gallus gallus), Turkey (Meleagris gallopavo), Indian Peafowl (Pavo cristatus), Northern Bobwhite (Colinus virginianus), Common Quail (Coturnix coturnix) and Mallard (Anas platyrhynchos) samples were obtained from the Michigan State University poultry farm, East Lansing, MI, USA; Racing Homer pigeons (Columba livia) and House Wren (Troglodytes aedon) being also sampled for analysing at the Michigan State University. A wide range of birds was sampled at the San Diego Zoo and San Diego Zoo Safari Park, Escondido, CA, USA. Additional avian samples were obtained from the collections at Indiana State University as well as at the State Poultry Research Station, Birky, Ukraine, and Kharkiv Zoo, Kharkiv, Ukraine.

One $\mathrm{mL}$ or $200 \mu \mathrm{l}$ (in the case of small birds like the House Wren) whole blood samples of at least one male and/or one female of each species were collected, and DNA was phenol-chloroform extracted following standard protocols (e.g. [25]). Similar procedures were employed for DNA extraction from Domestic Chicken embryo tissues (spleen, gonad) and avian myeloblastosis virus-transformed cell lines. The latter were derived from six-day-old transgenic ADOL Line 0 chicks (J.B. Dodgson and W.S. Payne, unpublished data). Selected BAC clones were identified in a gridded genomic Red Jungle Fowl BAC library (TAMU library code 031-JF256-BI; [26]), and their DNAs were isolated as described elsewhere [27]. Blood samples of Ukrainian origin birds were obtained using DNA-Sorb-B (InterLabService, Moscow, Russian Federation) filter paper and were treated according to the manufacturer's protocol. DNA was eluted from the sorbent using TE buffer $(50 \mu \mathrm{l})$. A subset of samples from Indiana State University were extracted from tissue using the magnetic extraction DNA IQ ${ }^{\mathrm{TM}}$ System (Promega, Madison, WI, USA). A single individual from certain species was used for testing if the specimen demonstrated sexually dimorphic plumage.

\section{PCR procedure and primer design}


PCR was performed in 10,15 , or $25 \mu \mathrm{l}$ volumes including up to $50 \mathrm{ng}$ genomic DNA, 40 to $300 \mathrm{nM}$ of each primer, 1X Taq polymerase buffer (Life Technologies, Rockville, MD, USA), $1.5 \mathrm{mM} \mathrm{MgCl}, 200 \mu \mathrm{M}$ dNTP, and 0.5 or 1 unit Taq polymerase (Life Technologies, Rockville, MD, USA). The settings for the thermal cycler were the following: hot start at $94{ }^{\circ} \mathrm{C}(2 \mathrm{~min})$ followed by 40 cycles including denaturing at 94 ${ }^{\circ} \mathrm{C}(30 \mathrm{~s})$, primer annealing at an appropriate temperature $(1 \mathrm{~min})$, elongation at $72{ }^{\circ} \mathrm{C}$ (2 min), and final extension at $72{ }^{\circ} \mathrm{C}(10 \mathrm{~min})$. All PCR assays were optimised and replicated to maximise reproducibility. As PCR enhancers in optimisation and experimental trials, tetramethyl ammonium chloride (TMAC) and bovine serum albumin (BSA) were exploited in several cases.

The following Domestic Chicken CHD1-based sexing PCR primers (Fig. 1) were tested: (1) P2 [5'-TCTGCATCGCTAAATCCTTT-3'] and P3 [5'AGATATTCTGGATCTGATAGTGA-3'] [19] at annealing temperature $54{ }^{\circ} \mathrm{C}$ using post-PCR digestion with restriction enzymes (Table 1); (2) P8 [5'-

CTCCCAAGGATGAGRAAYTG-3'] and P2 [5'-TCTGCATCGCTAAATCCTTT-3'] [20] using annealing temperature $48{ }^{\circ} \mathrm{C}$ (Table 2); (3) 1237L [5'-

GAGAAACTGTGCAAAACAG-3'] and 1272H [5'-TCCAGAATATCTTCTGCTCC$\left.3^{\prime}\right]$ [21] using annealing temperature $56^{\circ} \mathrm{C}$ and $1 \mathrm{mM}$ TMAC as a PCR enhancer (Table 3); and (4) 2550F [5'-GTTACTGATTCGTCTACGAGA-3'] and 2718R [5'ATTGAAATGATCCAGTGCTTG-3'] [22], with the annealing temperature being 52 ${ }^{\circ} \mathrm{C}$ (Table 4).

To seek new sexing markers, a Turkey $A D 012 \mathrm{~W}$ cDNA sequence (NCBI GenBank Accession No. AY188758) was used that is homologous to the human ubiquitin associated protein 2 (UBAP2) gene (NM_018449) and, by analogy with the Domestic Chicken UBAP2 genes (NM_001277104, NM_001277105), has both Z and W chromosome copies. Using the program PrimerSelect (computer software package Lasergene99, DNASTAR, Madison, WI, USA), the following primers were designed: 166F [5'-GGTGTACCGCCCTTGTTG-3'] and 279R [5'CATTGGCAGCCTGGATTGAA-3'] within the putative exon 1, and 815F [5'- 
CCTGATATCAGTGGCTCTGTCTA-3'] and 906R [5'-

GAGGGCATGCTGAAAGGAGGTG-3'] within the putative exon 3 (Table 5).

PCR products were analysed by running on $1 \%$ to $5 \%$ agarose gels in $1 \mathrm{X}$ TAE or TBE buffer, typically at $5 \mathrm{~V} / \mathrm{cm}$ for 2 hours, and visualizing with ethidium bromide under UV light. Alternatively, amplicons were analysed using capillary electrophoresis in an ABI PRISM $310 \AA$ automated sequencer and analysed with the Genotyper ${ }^{\circledR}$ program (Applied Biosystems, Foster City, CA, USA).

\section{CHD1 sequencing}

CHD1 PCR fragments were produced with $1237 \mathrm{~L}$ and $1272 \mathrm{H}$ primers [21] using DNA templates from the Red Jungle Fowl, Turkey, Indian Peafowl, Northern Bobwhite, Common Quail and Mallard. The corresponding Z and W chromosome bands were excised from the gel, and DNA was extracted using QIAquick Gel Extraction Kit with microcentrifuge spin columns or QIAEX II Gel Extraction Kit using sodium iodide and silica-gel particles (QIAGEN, Valencia, CA, USA). All subcloning was done in the pCR ${ }^{\circledR}$ 2.1-TOPO vector using the TOPO ${ }^{\mathrm{TM}}$ TA Cloning ${ }^{\circledR}$ Kit (Invitrogen, Carlsbad, CA, USA). Sequencing was performed on an ABI377 sequencer (PerkinElmer, Boston, MA, USA) using cycle sequencing reactions with dye labelled M13 universal or reverse primers. The nucleotide sequence data reported in this paper have been submitted to the NCBI GenBank nucleotide sequence database and have been assigned the Accession No. AY775803.

\section{Sequence analysis}

Local sequence alignments were performed using the Basic Local Alignment Search Tool (BLAST; [28]). Multiple alignments of avian $C H D 1 Z$ and $C H D 1 W$ sequences were done using Windows 32 MegAlign (DNASTAR, Madison, WI, USA). Alignments of sequences were performed using the CLUSTAL V and CLUSTAL W methods (as described in [29] and [30]), and were deposited in the EMBL-Align database [31] under accession numbers ALIGN_000994-ALIGN_000996 and ALIGN_000998ALIGN_001000. 


\section{RESULTS}

\section{CHD1: P2 / P3 primers}

We tested the original CHD1-based primer set [19] for sex identification based on the PCR-RFLP technique, i.e., PCR amplification coupled with post-PCR restriction enzyme digestion (Table 1). In all 14 species studied (belonging to seven avian orders), the sex dimorphism in the post-PCR restriction pattern was observed.

\section{CHD1: P8 / P2 primers}

We first validated this $C H D 1$-based sexing marker on male and female pairs of four bird species: Common Pheasant (Phasianus colchicus), Budgerigar (Melopsittacus undulates), Red-fan Parrot (Deroptyus accipitrinus), and European Herring Gull (Larus argentatus) (Fig. 2a, b). As expected, the male samples produced one amplicon, and the females two.

Furthermore, we confirmed the applicability of this test on 24 other birds of known sex including Domestic Chicken (Fig. 2a), Turkey, Guinea Fowl (Numida meleagris), Silver Pheasant (Lophura nycthemera) (Fig. 2a), African Grey Parrot (Psittacus erithacus) (Fig. 2b), White Stork (Ciconia ciconia) (Fig. 2a), American Woodcock (Scolopax minor), Great Horned Owl (Bubo virginianus), Mourning Dove (Zenaida macroura), and 15 passeriforms: Northern Cardinal (Cardinalis cardinalis), American Crow (Corvus brachyrhynchos), Common Yellowthroat (Geothlypis trichas), Dark-eyed Junco (Junco hyemalis), Northern Waterthrush (Parkesia noveboracensis), House Sparrow (Passer domesticus), Ovenbird (Seiurus aurocapilla), American Redstart (Setophaga ruticilla), Eastern Bluebird (Sialia sialis), European Starling (Sturnus vulgaris), Brown Thrasher (Toxostoma rufum), American Robin (Turdus migratorius), Hooded Warbler (Setophaga citrina), White-throated Sparrow (Zonotrichia albicollis), and White-crowned Sparrow (Zonotrichia leucophrys) (data not shown).

To expand the range of the assay further, we tested a wider range of birds using DNA samples available at the San Diego Zoo, San Diego Zoo Safari Park, and Indiana State University. The results of molecular sexing tests in a total of 72 avian 
species/subspecies are summarised in Table 2. In all these trials, there was a significant variation in PCR product length depending on the species, although a common pattern of sex differences was observed in most cases, with males showing one PCR band and females showing two PCR bands. We were unable to identify sex-specific bands in the Saker Falcon (Falco cherrug), White-tailed Eagle (Haliaeetus albicilla), and Steller's Sea Eagle (Haliaeetus pelagicus). There were also no sex differences in the Cinereous Vulture (Aegypius monachus) and Griffon Vulture (Gyps fulvus), so we additionally examined if distinguishing fragments could be obtained after post-PCR digestion with BamHI. The gender of two Bearded Vulture (Gypaetus barbatus) females was confirmed using both P8 / P2 primers and post-PCR digestion with BamHI.

\section{CHD1: 2550F / 2718R primers}

When using primers developed by Fridolfsson and Ellegren [22], males of all galliform species studied displayed one $600 \mathrm{bp}, \mathrm{Z}$-specific fragment, whereas females showed both $C H D I Z$ (600 bp) and CHDIW (450-bp) fragments (Fig. 3, S4). Both Mallard sexes yielded a single product of 600 bp (Fig. 3b). Two CHD1-specific Red Jungle Fowl BACs, JB057N16 and JB059N09, also produced a Z copy fragment, thus confirming that they harboured the CHDIZ gene (Fig. 3a). Sexes were also distinguishable in the domestic pigeon using these primers (Fig. 4a) and generating a W fragment of similar size to those of the other birds, but a $\mathrm{Z}$ fragment was slightly larger (about $650 \mathrm{bp}$ ). However, this primer set failed to identify sex-specific bands in the House Wren (Fig. $4 \mathrm{~b}$; data shown for a female sample only). The test data for this sexing marker are summarised in Table 3.

\section{CHD1: 1237L / 1272H primers}

Using primers designed by Kahn et al. [21], three galliform species, Red Jungle Fowl/Domestic Chicken, Turkey and Indian Peafowl, displayed one Z-specific fragment (240 bp) in males and two fragments (240 and $265 \mathrm{bp}$ ) in females. Only a single fragment was obtained, irrespective of sex, in Northern Bobwhite (250 bp), Common Quail (276 bp) and Mallard (240 bp) (data not shown). The Kahn et al. [21] primer amplification failed in Domestic Pigeon and House Wren samples of either sex. 
A CHD1 fragment amplified with Kahn et al. [21] primers was cloned and sequenced from the Common Quail only. However, its sequence (AY775803) was identical in both the male and female.

Based on the White-throated Sparrow BAC CH264-158I02 sequence (NCBI GenBank Accession No. AC237007), a modified reverse primer, 1272Hzal, was designed: [5'TCCAGAGTATCTTCT믇CC -3']. It differed from the original reverse primer 1272 at the two specified nucleotides, and was utilised to improve the sexing assay for the White-throated Sparrow, especially in cases when DNA was recovered from old/difficult samples. We assessed both the original and modified reverse primer on a variety of White-throated Sparrow male and female samples as well as individual samples of 17 other species of known sex from four orders. The Northern Cardinal, Eastern Bluebird, and American Redstart specimens all demonstrated plumage characteristics that allowed for sex determination prior to genetic analysis. Our DNA results agreed with the dimorphic characteristics observed. Overall, this sexing marker efficiently worked in 30 out of 33 species tested (Table 4). Our data showed that the modified primer set worked perfectly in amplifying CHDl fragments in the Whitethroated Sparrow and other passerines, even using old/difficult samples.

\section{UBAP2: 166F / 279R primers}

Based on the turkey UBAP2 cDNA sequence (AY188758), a new primer pair, 166F / 279R, was designed that enabled molecular sexing in three galliform birds: Red Jungle Fowl, Turkey and Indian Peafowl (Fig. 5a; Table 4). A single amplified fragment in the males ( $\mathrm{Z}$ copy) was $\sim 550$ bp long, whereas in the females there were two bands: $\sim 550$ bp (Z copy) and $\sim 1000$ bp (W copy). Similar fragments were obtained in sexing the Domestic Chicken embryo samples (spleen and gonad tissues) and cell lines (data not shown). On the other hand, there was a single amplification product in the Northern Bobwhite (1000 bp), Common Quail (550 bp) and Mallard (1000 bp) males and females (Fig. 5a). A single 1000-bp band was also obtained in both male and female Domestic Pigeon using the UBAP2 primers (Fig. 5b). 
In the House Wren, the UBAP2 primers generated an amplicon similar in the length to the $U B A P 2 W$ gene fragment ( $1000 \mathrm{bp}$ ), regardless of sex (data not shown).

\section{DISCUSSION}

Most currently used molecular techniques for sexing birds involve differential PCR amplification in males and females of the chromodomain-helicase-DNA-binding gene with two sex chromosome-specific copies, $C H D 1 Z$ and $C H D 1 W$, and we successfully tested four of these [19-22] across 13 avian orders. We also describe a novel sexspecific marker system based on the presence of $\mathrm{Z}$ and $\mathrm{W}$ copies of the UBAP2 gene [32-34]. This marker enabled us to accurately distinguish gender between males and females in three closely related galliform species: Domestic Chicken/Red Jungle Fowl, Turkey, and Indian Peafowl. Its advantage compared to other methods of sexing birds is a pronounced size difference between the Z- (550 bp) and W-linked (1000 bp) amplified fragments. This provides a reliable method that does not require special gel electrophoresis conditions, as compared to the other tested markers with less obvious differences between the sex-specific bands, e.g. in the case of the Kahn et al. [21] primers producing a $25 \mathrm{bp}$ difference. It also does not require application of the PCRRFLP technique using post-PCR cleavage with restriction endonucleases, in order to distinguish between male and female PCR fragments of similar size, as was the case of the Griffiths and Tiwari [19] primer set and in a few species tested with [20] primers that required further Bam $\mathrm{HI}$ digestion.

Our data showed that the three widely domesticated galliform birds (Domestic Chicken/Red Jungle Fowl, Turkey, Indian Peafowl) can be sexed using any of the three tested DNA markers, and gender in two most common galliform poultry species, Domestic Chicken and Turkey, can be determined using four molecular markers (Tables 2 to 5). However, two quail species were successfully sexed in our hands with only the Fridolfsson and Ellegren [22] primers, and we were able to identify gender in the Mallard, the progenitor of domestic ducks, by means of the Griffiths et al. [20] primers alone. 
In monomorphic avian species, in which both genders are similar, e.g. Domestic Pigeon and House Wren, development of molecular sexing markers would be beneficial. Although we succeeded in applying the Fridolfsson and Ellegren [22] primers for sex identification in the Domestic Pigeon, the methods tested failed in the House Wren. An effective approach would be to subclone and sequence the male and female amplified fragments that are of equal length but could potentially differ in nucleotide sequence at a certain restriction enzyme site. Indeed, Albrecht [35] reported a successful implementation of the Griffiths and Tiwari [19] marker coupled with the HaeIII digestion that generated two smaller fragments of the $\mathrm{W}$-linked fragments in the House Wren females.

Our experiments demonstrated that the choice of an appropriate, working molecular marker for sex identification in birds may depend on various factors including species tested, DNA sample/template quality, and primer/equipment availability. Use of enhancers/additives (e.g. TMAC) and a greater agarose gel concentration (up to 5\%) could assist respectively for PCR optimisation and for a better amplicon band separation in cases when the sex chromosome-specific amplification fragments are very similar in size.

The molecular sexing assays described here and by other researchers can be useful in breeding management of domestic and wild galliforms and pigeons as well as in a variety of studies on other wild avian species including population genetics, population demography and structure, paternity verification, and conservation applications (e.g. [36]). They can also be effectively applied for identifying BAC clones that harbour sexlinked genes and markers in molecular genetics and genomics studies (e.g. physical mapping; [26], Romanov and Dodgson 2006) and for gene sequencing (as shown in this study for the Common Quail CHD1 gene fragment). It is noteworthy that we efficiently employ molecular sex markers in the research projects focusing on the endangered California Condor and the White-throated Sparrow, a novel avian behavioural model (e.g. [38-40]). Also, the DNA tests for sex determination in chicken embryos and cell culture lines that were successful in our hands confirm utility of molecular sexing 
markers in embryology, transgenesis research, and search of in ovo sex identification techniques (e.g. [41]).

\section{ACKNOWLEDGEMENTS}

The work was supported by grants from the United States Department of Agriculture/Cooperative State Research, Education, and Extension Service (99-352058566 and 2001-52100-11225) to J.B. Dodgson, and from the National Institutes of Health (R01GM084229) to E.M. Tuttle and R.A. Gonser. We are most grateful to Hans Ellegren (Uppsala University, Uppsala, Sweden) and Nate Kahn (University of Denver, Denver, CO, USA) for sharing aliquots of the sexing primers, $2550 \mathrm{~F} / 2718 \mathrm{R}$ and 1237L / 1272H, respectively. We also thank Hans Ellegren for providing us with the UBAP2 sequence information, and Hans Cheng (USDA-ARS Avian Disease and Oncology Laboratory, East Lansing, MI, USA) for sequencing the common quail CHD1 fragments. Natalie Dubois (Michigan State University, East Lansing, MI, USA) is acknowledged for sharing the House Wren DNA samples, and Tanya Romanov (Michigan State University, East Lansing, MI, USA) and Sarah Ford (Indiana State University, Terre Haute, IN, USA) for technical assistance. We thank Olga Krestinina (Zelenodolsk, Russia) for graphical work.

\section{REFERENCES}

1. Millar, C.D., Lambert, D.M., Anderson, S. and Halverson, J.L., Molecular sexing of the communally breeding pukeko: an important ecological tool, Mol. Ecol., 1996, vol. 5, no. 2, pp. 289-293. https://onlinelibrary.wiley.com/doi/10.1046/j.1365294X.1996.00076.X

2. Ellegren, H. and Fridolfsson, A.K., Male-driven evolution of DNA sequences in birds, Nat. Genet., 1997, vol. 17, no. 2, pp. 182-184. https://doi.org/10.1038/ng1097182

3. Lessells, K., More mutations in males, Nature, 1997, vol. 390, no. 6657, pp. 236237. https://doi.org/10.1038/36745 
4. Kahn, N.W. and Quinn, T.W., Male-driven evolution among Eoaves? A test of the replicative division hypothesis in a heterogametic female (ZW) system, J. Mol. Evol., 1999, vol. 49, no. 6, pp. 750-759. https://doi.org/10.1007/PL00006597

5. Robertson, B.C., Millar, C.D., Minot, E.O. et al., Sexing the critically endangered kakapo Strigops habroptilus, Emu, 2000, vol. 100, no. 4, pp. 336-339. https://doi.org/10.1071/MU00056

6. Bermudez-Humaran, L.G., Garcia-Garcia, A., Leal-Garza, C.H. et al., Molecular sexing of monomorphic endangered Ara birds, J. Exp. Zool., 2002, vol. 292, no. 7 , pp. 677-680. https://doi.org/10.1002/jez.10070

7. Romanov, M.N. and Bondarenko, Y.V., Use of autosexing in waterfowl breeding and production (Proc. 10th Europ. Symp. Waterfowl), Halle, 1995, pp. 473-476.

8. Wang, N. and Shoffner, R.N., Trypsin G- and C-banding for interchange analysis and sex identification in the chicken, Chromosoma, 1974, vol. 47, no. 1, pp. 61-69. https://doi.org/10.1007/BF00326271

9. Nakamura, D., Tiersch, T.R., Douglass, M. and Chandler, R.W., Rapid identification of sex in birds by flow cytometry, Cytogenet. Cell Genet., 1990, vol. 53, no. 4, pp. 201-205. https://doi.org/10.1159/000132930

10. De Vita, R., Cavallo, D., Eleuteri, P. and Dell'Omo, G., Evaluation of interspecific DNA content variations and sex identification in Falconiformes and Strigiformes by flow cytometric analysis, Cytometry, 1994, vol. 16, no. 4, pp. 346350. https://doi.org/10.1002/cyto.990160409

11. Kagami, H., Nakamura, H. and Tomita, T., Sex identification in chickens by means of the presence of the $\mathrm{W}$ chromosome specific repetitive DNA units, Jpn. Poult. Sci., 1990, vol. 27, no. 5, pp. 379-384. https://doi.org/10.2141/jpsa.27.379

12. Cassar, G., Mohammed, M., John, T.M. et al., Differentiating between parthenogenetic and "positive development" embryos in turkeys by molecular sexing, Poultry Sci., 1998, vol. 77, no. 10, pp. 1463-1468.

https://doi.org/10.1093/ps/77.10.1463

13. D'Costa, S. and Petitte, J.N., Sex identification of turkey embryos using a multiplex polymerase chain reaction, Poultry Sci., 1998, vol. 77, no. 5, pp. 718-721. https://doi.org/10.1093/ps/77.5.718 
14. Trefil, P., Bruno, M.M., Mikus, T. and Thoraval, P., Sexing of chicken feather follicle, blastodermal and blood cells, Folia Biol. (Praha), 1999, vol. 45, no. 6, pp. $253-256$.

15. Ogawa, A., Solovei, I., Hutchison, N. et al., Molecular characterization and cytological mapping of a non-repetitive DNA sequence region from the $\mathrm{W}$ chromosome of chicken and its use as a universal probe for sexing Carinatae birds, Chromosome Res., 1997, vol. 5, no. 2, pp. 93-101. https://doi.org/10.1023/A:1018461906913

16. Ellegren, H., First gene on the avian W chromosome (CHD) provides a tag for universal sexing of non-ratite birds, Proc. R. Soc. Lond. B Biol. Sci., 1996, vol. 263, no. 1377, pp. 1635-1641. https://doi.org/10.1098/rspb.1996.0239

17. Griffiths, R., Daan, S. and Dijkstra, C., Sex identification in birds using two CHD genes, Proc. R. Soc. Lond. B Biol. Sci., 1996, vol. 263, no. 1374, pp. 12511256. https://doi.org/10.1098/rspb.1996.0184

18. Griffiths, R. and Korn, R.M., A CHDl gene is Z chromosome linked in the chicken Gallus domesticus, Gene, 1997, vol. 197, no. 1-2, pp. 225-229. https://doi.org/10.1016/S0378-1119(97)00266-7

19. Griffiths, R. and Tiwari, B., Sex of the last wild Spix's macaw, Nature, 1995, vol. 375, no. 6531, p. 454. https://doi.org/10.1038/375454a0

20. Griffiths, R., Double, M.C., Orr, K. and Dawson, R.J., A DNA test to sex most birds, Mol. Ecol., 1998, vol. 7, no. 8, pp. 1071-1075. https://doi.org/10.1046/j.1365294x.1998.00389.x

21. Kahn, N.W., St John, J. and Quinn, T.W., Chromosome-specific intron size differences in the avian CHD gene provide an efficient method for sex identification in birds, Auk, 1998, vol. 115, no. 4, pp. 1074-1078. https://doi.org/10.2307/4089527

22. Fridolfsson, A.K. and Ellegren, H., A simple and universal method for molecular sexing of non-ratite birds, J. Avian Biol., 1999, vol. 30, no. 1, pp. 116121. https://doi.org/10.2307/3677252

23. Kerje, S., Sharma, P., Gunnarsson, U. et al., The Dominant white, Dun and Smoky color variants in chicken are associated with insertion/deletion polymorphisms in the PMEL17 gene, Genetics, 2004, vol. 168, no. 3, pp. 15071518. https://doi.org/10.1534/genetics.104.027995 
24. Crittenden, L.B., Provencher, L., Santangelo, L. et al., Characterization of a Red Jungle Fowl by White Leghorn backcross reference population for molecular mapping of the chicken genome, Poultry Sci., 1993, vol. 72, no. 2, pp. 334-348. https://doi.org/10.3382/ps.0720334

25. Seutin, G., White, B.N. and Boag, P.T., Preservation of avian blood and tissue samples for DNA analyses, Can. J. Zool., 1991, vol. 69, no. 1, pp. 82-90. https://doi.org/10.1139/z91-013

26. Lee, M.K., Ren, C.W., Yan, B. et al., Construction and characterization of three BAC libraries for analysis of the chicken genome, Anim. Genet., 2003, vol. 34, no. 2, pp. 151-152. https://doi.org/10.1046/j.1365-2052.2003.00965_5.x

27.

https://web.archive.org/web/20100709231600/http://hbz7.tamu.edu/homelinks/t ool/bac_content.htm.

28. Madden, T.L., Tatusov, R.L. and Zhang, J., Applications of network BLAST server, Methods Enzymol., 1996, vol. 266, pp. 131-141.

29. Higgins, D.G. and Sharp, P.M., Fast and sensitive multiple sequence alignments on a microcomputer, Comput. Appl. Biosci., 1989, vol. 5, no. 2, pp. 151-153. https://doi.org/10.1093/bioinformatics/5.2.151

30. Thompson, J.D., Higgins, D.G. and Gibson, T.J., CLUSTAL W: improving the sensitivity of progressive multiple sequence alignment through sequence weighting, position-specific gap penalties and weight matrix choice, Nucleic Acids Res., 1994, vol. 22, no. 22, pp. 4673-4680. https://doi.org/10.1093/nar/22.22.4673

31. Lombard, V., Camon, E.B., Parkinson, H.E. et al., EMBL-Align: a new public nucleotide and amino acid multiple sequence alignment database, Bioinformatics, 2002, vol. 18, no. 5, pp. 763-764. https://doi.org/10.1093/bioinformatics/18.5.763

32. Axelsson, E., Smith, N.G.C., Sundström, H. et al., Male-biased mutation rate and divergence in autosomal, Z-linked and W-linked introns of chicken and turkey, Mol. Biol. Evol., 2004, vol. 21, no. 8, pp. 1538-1547.

https://doi.org/10.1093/molbev/msh157

33. Lawson Handley, L.J., Ceplitis, H. and Ellegren, H., Evolutionary strata on the chicken Z chromosome: implications for sex chromosome evolution, Genetics, 2004, vol. 167, no. 1, pp. 367-376. https://doi.org/10.1534/genetics.167.1.367 
34. Sazanov, A.A., Sazanova, A.L., Stekolnikova, V.A. et al., Chromosomal localization of the UBAP2Z and UBAP2W genes in chicken, Anim. Genet., 2006, vol. 37, no. 1, pp. 72-73. https://doi.org/10.1111/j.1365-2052.2005.01392.x

35. Albrecht, D.J., Sex ratio manipulation within broods of house wrens, Troglodytes aedon, Anim. Behav., 2000, vol. 59, no. 6, pp. 1227-1234. https://doi.org/10.1006/anbe.1999.1420

36. Romanov, M.N., Kutnyuk, P.I. and Chernikov, V.F., Estimation of population structure and differentiation in black-headed gull by using genetic/oological parameters. 1. Analysis within an East-Ukrainian population, J. Ornithol., 1994, vol. 135, no. 1, p. 261. https://doi.org/10.1007/BF02445773

37. Romanov, M.N. and Dodgson, J.B., Cross-species overgo hybridization and comparative physical mapping within avian genomes, Anim. Genet., 2006, vol. 37, no. 4, pp. 397-399. https://doi.org/10.1111/j.1365-2052.2006.01463.x

38. Romanov, M.N., Koriabine, M., Nefedov, M. et al., Construction of a California condor BAC library and first-generation chicken-condor comparative physical map as an endangered species conservation genomics resource, Genomics, 2006, vol. 88, no. 6, pp. 711-718. https://doi.org/10.1016/j.ygeno.2006.06.005

39. Romanov, M.N., Tuttle, E.M., Houck, M.L. et al., The value of avian genomics to the conservation of wildlife, BMC Genomics, 2009, vol. 10, suppl. 2, p. S10. https://doi.org/10.1186/1471-2164-10-S2-S10

40. Romanov, M.N., Dodgson, J.B., Gonser, R.A. and Tuttle, E.M., Comparative BAC-based mapping in the white-throated sparrow, a novel behavioral model, using interspecies overgo hybridization, BMC Res. Notes, 2011, vol. 4, p. 211. https://doi.org/10.1186/1756-0500-4-211

41. Narushin, V.G., Romanov, M.N. and Bogatyr, V.P., Method for preincubational prediction of embryo sex in chicken eggs (Proc. 8th World Conf. Anim. Prod.), Seoul, 1998, vol. 1, pp. 832-833. 
Table 1. Test results using the Griffiths and Tiwari (1995) sexing primers in 14 avian species/subspecies

\begin{tabular}{lc}
\hline Species (by order) & $\mathrm{P} 2 / \mathrm{P} 3$ \\
\hline Ciconiiformes & + \\
African Openbill Stork (Anastomus lamelligerus) & + \\
Painted Stork (Mycteria leucocephala) & + \\
Columbiformes & \\
Coroneted Fruit-dove (Ptilinopus coronulatus & + \\
$\quad$ trigeminus) & + \\
Western Orange-bellied Fruit-dove (P. iozonus & + \\
$\quad$ humeralis) & + \\
Jambu Fruit-dove (P. jambu) & + \\
Sulawesi Superb Fruit-dove (P. superbus temminckii) & \\
Pink-necked Green Pigeon (Treron vernans purpurea) & + \\
Falconiformes & + \\
Harpy Eagle (Harpia harpyja) & + \\
Gruiformes & + \\
Sandhill Crane (Grus canadensis) & + \\
Kagu (Rhynochetos jubatus) & + \\
Passeriformes & + \\
San Clemente loggerhead shrike (Lanius ludovicianus \\
mearnsi) & \\
Po'ouli (Melamprosops phaesoma) & \\
Procellariiformes & + \\
Black-footed albatross (Phoebastria nigripes) & \\
Cockatoo (Cacatua sp.) & \\
\hline & + \\
\hline
\end{tabular}

'+', sex dimorphism in band pattern. 
Table 2. Test results using the Griffiths et al. (1998) sexing primers in 72 avian species/subspecies

\begin{tabular}{|c|c|}
\hline Species (by order) & $\mathrm{P} 8 / \mathrm{P} 2$ \\
\hline \multicolumn{2}{|l|}{ Anseriformes } \\
\hline Mallard (Anas platyrhynchos) & + \\
\hline Black Swan (Cygnus atratus) & + \\
\hline \multicolumn{2}{|l|}{ Cathartiformes $^{\mathrm{a}}$} \\
\hline California Condor (Gymnogyps californianus) & + \\
\hline \multicolumn{2}{|l|}{ Charadriiformes } \\
\hline European Herring Gull (Larus argentatus) & + \\
\hline American Woodcock (Scolopax minor) & $\mathrm{B}$ \\
\hline \multicolumn{2}{|l|}{ Ciconiiformes } \\
\hline White Stork (Ciconia ciconia) & + \\
\hline \multicolumn{2}{|l|}{ Columbiformes } \\
\hline Mourning Dove (Zenaida macroura) & $\mathrm{B}$ \\
\hline \multicolumn{2}{|l|}{ Cuculiformes } \\
\hline Violet Turaco (Musophaga violacea) & + \\
\hline $\begin{array}{l}\text { Northern Chestnut-breasted Malkoha (Phaenicopha } \\
\text { singularis) }\end{array}$ & + \\
\hline Red-billed Malkoha (Ph. javanicus) & + \\
\hline Guinea Turaco (Tauraco persa) & + \\
\hline \multicolumn{2}{|l|}{ Falconiformes } \\
\hline Cinereous Vulture (Aegypius monachus) & $+^{\mathrm{b}}$ \\
\hline Saker Falcon (Falco cherrug) & - \\
\hline Bearded Vulture (Gypaetus barbatus) & $\mathrm{B}^{\mathrm{c}}$ \\
\hline Griffon Vulture (Gyps fulvus) & $+^{\mathrm{b}}$ \\
\hline White-tailed Eagle (Haliaeetus albicilla) & - \\
\hline Steller's Sea Eagle (H. pelagicus) & - \\
\hline \multicolumn{2}{|l|}{ Galliformes } \\
\hline White Eared Pheasant (Crossoptilon crossoptilon) & + \\
\hline Domestic Chicken (Gallus gallus) & + \\
\hline Silver Pheasant (Lophura nycthemera) & + \\
\hline Turkey (Meleagris gallopavo) & + \\
\hline Guinea Fowl (Numida meleagris) & + \\
\hline
\end{tabular}


Common Pheasant (Phasianus colchicus)

Gruiformes

Kagu (Rhynochetos jubatus)

Passeriformes

Common Myna (Acridotheres tristis)

Northern Cardinal (Cardinalis cardinalis)

A

American Crow (Corvus brachyrhynchos)

A

Common Yellowthroat (Geothlypis trichas)

A

Dark-eyed Junco (Junco hyemalis)

A

San Clemente Loggerhead Shrike (Lanius ludovicianus mearnsi)

Po'ouli (Melamprosops phaesoma)

Northern Waterthrush (Parkesia noveboracensis)

A

House Sparrow (Passer domesticus)

Ovenbird (Seiurus aurocapillus)

American Redstart (Setophaga ruticilla)

A

Eastern Bluebird (Sialia sialis)

European Starling (Sturnus vulgaris)

B

Peruvian Blue-necked Tanager (Tangara cyanicollis cyanicollis)

Brown Thrasher (Toxostoma rufum)

American Robin (Turdus migratorius)

Hooded Warbler (Wilsonia citrina)

White-throated Sparrow (Zonotrichia albicollis)

White-crowned Sparrow (Z. leucophrys)

Psittaciformes

Blue-fronted Amazon (Amazona aestiva)

Orange-winged Amazon (A. amazonica)

Hyacinth Macaw (Anodorhynchus hyacinthinus)

Red-winged Parrot (Aprosmictus erythropterus)

Blue-and-yellow Macaw (Ara ararauna)

Green-winged Macaw (A. chloroptera)

Scarlet Macaw (A. macao)

Chestnut-fronted Macaw (A. severus)

Orange-fronted Parakeet (Aratinga canicularis)

Jandaya Parakeet (A. jandaya)

Sun Parakeet (A. solstitialis)

Port Lincoln Parrot (Barnardius z. zonarius) 
Sulphur-crested Cockatoo (Cacatua galerita) +

Salmon-crested Cockatoo (C. moluccensis) +

Spix’s Macaw (Cyanopsitta spixii)

Red-fan Parrot (Deroptyus accipitrinus) + +

Red-shouldered Macaw (Diopsittaca nobilis) + +

Galah (Eolophus roseicapilla) + +

Budgerigar (Melopsittacus undulatus) +

Monk Parakeet (Myiopsitta monachus) + +

Cockatiel (Nymphicus hollandicus) + +

Eastern Rosella (Platycercus eximius) + +

Red-fronted Parrot (Poicephalus gulielmi) + +

Senegal Parrot (P. senegalus) +

Regent Parrot (Polytelis anthopeplus) + +

Palm Cockatoo (Probosciger aterrimus) + +

Red-breasted Parakeet (Psittacula alexandri) + +

African Grey Parrot (Psittacus erithacus)

Strigiformes

Great Horned Owl (Bubo virginianus)

B

'+', sex dimorphism; '-', no sex dimorphism in band pattern; A, correctly identified sex of a single individual with known sexual phenotype; B, produced positive bands for sex determination but no phenotypic confirmation; F, failed PCR.

aOrder status is debatable. California Condor has also been placed in Falconiformes as well as Ciconiiformes.

${ }^{\text {b }}$ Sex differences were only obtained by BamHI digestion of the PCR products.

${ }^{\mathrm{c}}$ Two female samples were only available, and Z- and W-specific bands were produced after both PCR and post-PCR BamHI digestion. 
Table 3. Test results using the Fridolfsson and Ellegren (1999) sexing primers in nine avian species

\begin{tabular}{lc}
\hline Species (by order) & 2550F / 2718R \\
\hline Anseriformes & + \\
Mallard (Anas platyrhynchos) & \\
Columbiformes & + \\
Pigeon (Columba livia) & + \\
Galliformes & + \\
Common Quail (Coturnix coturnix) & + \\
Bobwhite Quail (Colinus virginianus) & + \\
Red Jungle Fowl (Gallus gallus) & + \\
Domestic Chicken (G. gallus) & - \\
Turkey (Meleagris gallopavo) & \\
Indian Peafowl (Pavo cristatus) & \\
Passeriformes & \\
House Wren (Troglodytes aedon) & \\
\hline
\end{tabular}

'+', sex dimorphism; '-', no sex dimorphism in band pattern. 
Table 4. Test results using the Kahn et al. (1998) sexing primers in 33 avian species/subspecies

\begin{tabular}{l} 
Species (by order) \\
\hline Anseriformes \\
Mallard (Anas platyrhynchos) \\
Cathartiformes $^{\mathrm{a}}$ \\
California Condor (Gymnogyps californianus)
\end{tabular}

1237L / 1272H

Charadriiformes

American Woodcock (Scolopax minor) ${ }^{\mathrm{b}}$

B

Columbiformes

Pigeon (Columba livia)

F

Mourning Dove (Zenaida macroura) ${ }^{\mathrm{b}}$

B

Galliformes

Common Quail (Coturnix coturnix)

Bobwhite Quail (Colinus virginianus)

Red Jungle Fowl (Gallus gallus)

Domestic Chicken (G. gallus)

Turkey (Meleagris gallopavo)

Indian Peafowl (Pavo cristatus)

Gruiformes

Kagu (Rhynochetos jubatus)

Passeriformes

Northern Cardinal (Cardinalis cardinalis) $^{\mathrm{b}} \quad$ A

American Crow (Corvus brachyrhynchos) ${ }^{\mathrm{b}}$ A

Common Yellowthroat (Geothlypis trichas) ${ }^{\mathrm{b}} \quad$ A

Dark-eyed Junco (Junco hyemalis) ${ }^{\mathrm{b}}$ A

San Clemente Loggerhead Shrike (Lanius ludovicianus mearnsi)

Po'ouli (Melamprosops phaesoma)

Northern Waterthrush (Parkesia noveboracensis) ${ }^{\mathrm{b}}$ A

House Sparrow (Passer domesticus) ${ }^{\mathrm{b}}$ A

Ovenbird (Seiurus aurocapillus) ${ }^{\mathrm{b}}$ A

Black-throated Blue Warbler (Setophaga caerulescens) ${ }^{\mathrm{b}} \quad$ F

American Redstart (S. ruticilla $)^{\mathrm{b}}$ A 
Eastern Bluebird (Sialia sialis) ${ }^{\mathrm{b}}+$

European Starling (Sturnus vulgaris) ${ }^{\mathrm{b}}$ B

Peruvian Blue-necked Tanager (Tangara c. cyanicollis) +

Brown Thrasher (Toxostoma rufum) ${ }^{\mathrm{b}} \quad$ B

House Wren (Troglodytes aedon) F

American Robin (Turdus migratorius) ${ }^{\mathrm{b}}$ A

Hooded Warbler (Wilsonia citrina) ${ }^{\mathrm{b}} \quad$ A

White-throated Sparrow (Zonotrichia albicollis) ${ }^{\mathrm{b}}+$

White-crowned Sparrow (Z. leucophrys) ${ }^{\mathrm{b}}$ A

Strigiformes

Great Horned Owl (Bubo virginianus) ${ }^{\mathrm{b}}$

B

‘+', sex dimorphism; '-', no sex dimorphism in band pattern; A, correctly identified sex of a single individual with known sexual phenotype; B, produced positive bands for sex determination but no phenotypic confirmation; F, failed PCR.

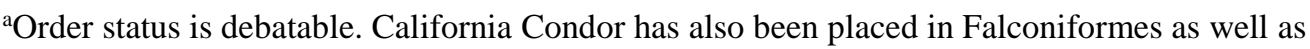
Ciconiiformes.

${ }^{\mathrm{b}}$ The modified primers 1237L / 1272Hzal were also used in this study. 
Table 5. Test results using the sexing primers based on $U B A P 2 Z$ vs. $U B A P 2 W$ sequence differences in nine avian species

\begin{tabular}{lc}
\hline Species (by order) & $166 \mathrm{~F} / 279 \mathrm{R}$ \\
\hline Anseriformes & - \\
Mallard (Anas platyrhynchos) & \\
Columbiformes & - \\
Pigeon (Columba livia) & - \\
Galliformes & + \\
Common Quail (Coturnix coturnix) & + \\
Bobwhite Quail (Colinus virginianus) & + \\
Red Jungle Fowl (Gallus gallus) & + \\
Domestic Chicken (G. gallus) & - \\
Turkey (Meleagris gallopavo) & \\
Indian Peafowl (Pavo cristatus) & \\
Passeriformes & \\
House Wren (Troglodytes aedon) &
\end{tabular}

'+', sex dimorphism; '-', no sex dimorphism in band pattern 


\section{Figure captions}

Fig. 1. Location of the CHDI gene-based sexing PCR primers (not on an exact scale): 2550F / 2718R (Fridolfsson and Ellegren 1999); Kahn 1237L / 1272H (Kahn et al. 1998); P8 / P2 (Griffiths et al. 1998); and P2 / P3 (Griffiths and Tiwari 1995). Exact positions of the primers on the chicken Z chromosome are: 2550F, 51,125,443..51,125,463; 2718R, 51,126,015..51,126,035; P8, 51,129,765..51,129,784; 1237L, $51,129,776 . .51,129,794 ; 1272 \mathrm{H}, 51,129,992 . .51,130,011 ; \mathrm{P} 3,51,130,000 . .51,130,022$; and P2,

$51,130,090 . .51,130,109$

Fig. 2. PCR sexing assays using the P8 / P2 primers: a Lanes: 1, Domestic Chicken female; 2, Indian Peafowl female; 3, Indian Peafowl female; 4, Common Pheasant female; 5, Common Pheasant male; 6, European Herring Gull male; 7, European Herring Gull female; 8, 9, White Stork males; 10, Budgerigar female; 11, Budgerigar male; 12, Silver Pheasant female. b Lanes: 1-4, African Grey Parrot males; 5, 7, 9, African Grey Parrot females; 6, 8, Red-fan Parrot females

Fig. 3. PCR sexing assays using the 2550F / 2718R primers (Fridolfsson and Ellegren 1999) and (a) 1.5 vs. (b) $3 \mathrm{mM} \mathrm{MgCl}_{2}$ concentration: a Lanes: 1, Indian Peafowl male; 2, Indian Peafowl female; 3 , Northern Bobwhite 1 male; 4, Northern Bobwhite female; 5, Common Quail male; 6, Common Quail female; 7, Domestic Chicken BAC JB057N16; 8, Domestic Chicken BAC JB059N09. b Lanes: 1, Turkey male; 2, Turkey female; 3, Mallard male; 4, Mallard female. M, 100-bp DNA ladder

Fig. 4. PCR sexing assays using the 2550F / 2718R primers (Fridolfsson and Ellegren 1999): a Lanes: 1, Pigeon male; 2, Pigeon female; 3, Red Jungle Fowl male; 4, Red Jungle Fowl female. M, 100-bp DNA ladder. b Lanes: 1, Red Jungle Fowl female; 2, Domestic Chicken Smoky line male; 3, Domestic Chicken Smoky line female; 4, House Wren female. M, $\lambda /$ HindIII fragments

Fig. 5 PCR sexing assays using the UBAP2-based primers: a Lanes: 1, Red Jungle Fowl male; 2, Red Jungle Fowl female; 3, Turkey male; 4, Turkey female; 5, Indian Peafowl male; 6, Indian Peafowl female; 7, Northern Bobwhite male; 8, Northern Bobwhite female; 9, Common Quail male; 10, Common Quail female; 11, Mallard male (failed); 12, Mallard female; M, 100-bp DNA ladder. b Lanes: 1, Pigeon male; 2, Pigeon female; 3, Red Jungle Fowl male; 4, Red Jungle Fowl female. M, $\lambda$ /HindIII fragments 